\title{
TEKNIK SHOOTING DALAM SEPAKBOLA
}

Arsyad Aras

\begin{abstract}
Abstrak
Sepak bola adalah cabang olahraga yang menggunakan bola sepak terbuat dari bahan kulit dan dimainkan oleh dua tim yang beranggotakan sebelas orang serta beberapa pemain cadangan". Untuk memenangkan permainan ini kedua tim harus memasukkan bola ke gawang lawan tanpa menggunakan tangan. Tim yang berhasil membobol bola ke gawang lawan paling banyak akan menjadi pemenangnya. Pada dasarnya shooting sangat di perlukan dalam permainana sepak bola karena inti dari sebuah permainan sepak bola yaitu gool yang di cetak melalui shooting, Teknik dasar sepak bola dapat meliputi teknik-teknik dalam menendang, menggiring, mengontrol, menyundul, merebut, melempar ke dalam.
\end{abstract}

Kata Kunci : Sepakbola, Teknik Dasar, Shooting

\begin{abstract}
Soccer is a sport that uses soccer balls made of leather and is played by two teams of eleven people and several reserve players ". To win this game both teams must put the ball into the opponent's goal without using their hands. The team that hits the ball against the most opponents will be the winner. Basically shooting is very much needed in a soccer game because the essence of a soccer game is a gool that is printed through shooting. The basic techniques of football can include techniques in kicking, dribbling, controlling, heading, grabbing, throwing in.
\end{abstract}

Keywords: Football, Basic Technique, Shooting 


\section{BAB I \\ PEBDAHULUAN}

\section{A. Latar Belakang}

Sepak bola (bahasa Inggris: Association Football, Football, atau Soccer), secara resmi dikenal sebagai sepak bola asosiasi, adalah cabang olahragayang menggunakan bola yang umumnya terbuat dari bahan kulit dan dimainkan oleh dua tim yang masing-masing beranggotakan 11 (sebelas) orang pemain inti dan beberapa pemain cadangan. Memasuki abad ke-21, olahraga ini telah dimainkan oleh lebih dari 250 juta orang di 200 negara, yang menjadikannya olahraga paling populer di dunia. Sepak bola bertujuan untuk mencetak gol sebanyak-banyaknya dengan memasukan bola ke gawang lawan. Sepak bola dimainkan dalam lapangan terbuka yang berbentuk persegi panjang, di atas rumput atau rumput sintetis.

Saat ini perkembangan permainan sepakbola sangat pesat sekali, hal ini ditandai dengan banyaknya sekolah-sekolah sepakbola (SSB) yang didirikan. Tujuan dari permainan sepakbola adalah masing-masing regu atau kesebelasan yaitu berusaha menguasai bola, memasukan bola ke dalam gawang lawan sebanyak mungkin, dan berusaha mematahkan serangan lawan untuk melindungi atau menjaga gawangnya agar tidak kemasukan bola. Permainan sepakbola merupakan permainan beregu yang memerlukan dasar kerjasama antar sesama anggota regu, sebagai salah satu ciri khas dari permainan sepakbola.Untuk bisa bermainan sepakbola dengan baik dan benar para pemain menguasai teknik-teknik dasar sepakbola. Untuk bermain bola dengan baik pemain dibekali dengan teknik dasar yang baik, pemain yang memiliki teknik dasar yang baik pemain tersebut cenderung dapat bermain sepakbola dengan baik pula. Teknik-teknik dasar dalam permainan sepakbola ada beberapa macam, seperti stop ball (menghentikan bola), shooting (menendang bola ke gawang), passing (mengumpan), heading (menyundul bola), dan dribbling (menggiring bola). 
B. Rumusan masalah

1. Apa pengertian olahraga sepak bola?

2. Bagaimana sejarah olahraga sepak bola?

3. Bagaimana melakukan teknik shooting pada olahraga sepak bola?

C. Tujuan

1. Mengetahui dan menjelaskan pengertian olahraga sepak bola

2. Mengetahui dan menjelaskan sejarah olahraga sepak bola

3. Mengetahui dan mampu menjelaskan sekaligus mempraktikan teknik shooting pada olahraga sepak bola 


\section{BAB II \\ PEMBAHASAN}

1. Pengertian Sepak Bola

Sepak bola adalah cabang olahraga yang menggunakan bola yang umumnya terbuat dari bahan kulit dan dimainkan oleh dua tim yang masing-masing beranggotakan 11 (sebelas) orang pemain inti dan beberapa pemain cadangan. Memasuki abad ke-21, olahraga ini telah dimainkan oleh lebih dari 250 juta orang di 200 negara, yang menjadikannya olahraga paling populer di dunia. Sepak bola bertujuan untuk mencetak gol sebanyak-banyaknya dengan memasukan bola ke gawang lawan. Sepak bola dimainkan dalam lapangan terbuka yang berbentuk persegi panjang, di atas rumput atau rumput sintetis.

Secara umum, hanya penjaga gawang saja yang berhak menyentuh bola dengan tangan atau lengan di dalam daerah gawangnya, sedangkan 10 (sepuluh) pemain lainnya diizinkan menggunakan seluruh tubuhnya selain tangan, biasanya dengan kaki untuk menendang, dada untuk mengontrol, dan kepala untuk menyundul bola. Tim yang mencetak gol paling banyak pada akhir pertandingan menjadi pemenangnya. Jika hingga waktu berakhir masih berakhir imbang, maka dapat dilakukan undian, perpanjangan waktu maupun adu penalti, bergantung pada format penyelenggaraan kejuaraan. Dari sebuah pertandingan resmi, 3 poin diberikan kepada tim pemenang, 0 poin untuk tim yang kalah dan masing-masing 1 poin untuk dua tim yang bermain imbang (Festiawan et al, 2020). Meskipun demikian, pemenang sebuah pertandingan sepak bola dapat dibatalkan sewaktu-waktu atas skandal dan tindakan kriminal yang terbukti di kemudian hari. Sebuah laga sepak bola dapat dimenangkan secara otomatis oleh sebuah timdengan 3-0 apabila tim lawan sengaja mengundurkan diri dari pertandingan (Walk Out).

\section{Sejarah Sepak Bola}

Sejarah olahraga sepak bola (permainan menendang bola) dimulai sejak abad ke-2 dan ke-3 sebelum Masehi di Tiongkok. Pada masa Dinasti Han tersebut, masyarakat menggiring bola kulit dengan menendangnya kejaring kecil. Permainan serupa juga dimainkan di Jepang dengan 
sebutan Kemari. Di Italia, permainan menendang dan membawa bola juga di gemari terutama mulai abad ke-16. Sepak bola modern mulai berkembang di Inggris dengan menetapkan peraturan-peraturan dasar dan menjadi sangat digemari oleh banyak kalangan. Di beberapa kompetisi, permainan ini menimbulkan banyak kekerasan selama pertandingan sehingga akhirnya Raja Edward III melarang olahraga ini dimainkan pada tahun 1365. Raja James I dari Skotlandia juga mendukung larangan untuk memainkan sepak bola. Pada tahun 1815, sebuah perkembangan besar menyebabkan sepakbola menjadi terkenal di lingkungan universitas dan sekolah. Kelahiran sepak bola modern terjadi di Freemasons Tavern pada tahun 1863 ketika 11 sekolah dan klub berkumpul dan merumuskan aturan baku untuk permainan tersebut. Bersamaan dengan itu, terjadi pemisahan yang jelas antara olahraga rugby dengan sepak bola (soccer). Pada tahun 1869, membawa bola dengan tangan mulai dilarang dalam sepak bola. Selama tahun 1800-an, olahraga tersebut dibawa oleh pelaut, pedagang, dan tentara Inggris ke berbagai belahan dunia. Pada tahun 1904, asosiasi tertinggi sepak bola dunia (FIFA) dibentuk dan pada awal tahun 1900-an, berbagai kompetisi dimainkan diberbagai negara. Olahraga ini juga digemari terutama mulai abad ke-16.

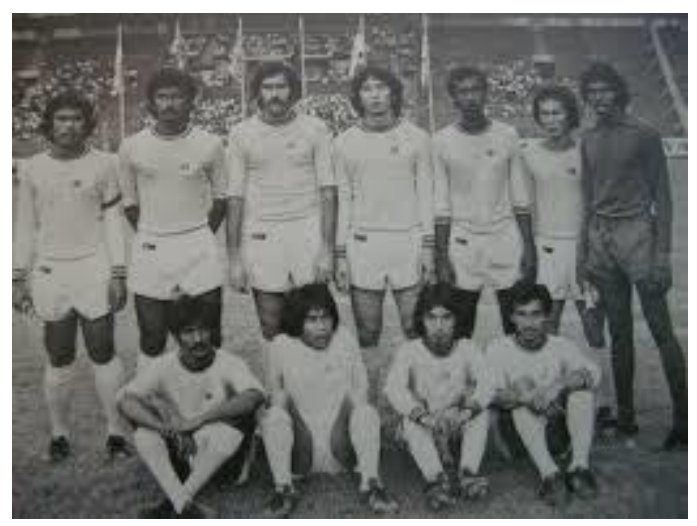

Gambar Tim Nasional Indonesia

3. Teknik Melakukan Shooting

Shooting dalam permainan sepakbola pada dasarnya hampir sama seperti dalam shooting pada permainan bola basket memiliki tujuan untuk mengarahkan bola ke arah sasaran goal dalam permainan sepakbola gawang yang dijaga oleh seorang penjaga gawang (Sinatriyo et al, 2020). 
Shooting sering dilakukan pada daerah mendekati kotak pinalti ke arah gawang oleh pemian penyerang seperti striker, gelandang dan sayap. Secara khusus tujuan melakukan shooting untuk memasukan bola ke arah gawang lawan dengan tendangan bola yang akurat menghindari halauan penjaga gawang.

Cara Melakukan Teknik Shooting Dalam Sepakbola dengan Benar

Bagi para pemula perhatikan betul tentang bagaimana cara melakukan shooting sepakbola dengan benar. Berikut cara melakukan shooting sepakbola dengan benar :

Awalan

- Ambil jarak dengan bola sejauh 1,5 meter

- Tempatkan bola di depan secara serong membentuk sudut 45 derajat

- Lari ke arah bola dengan melihat bgaian bola yang kan di tendang

Posisi Tubuh

- Lakukan kaki tumpuan dengan menempatkan telapak kaki disamping bola dengan jarak $30 \mathrm{~cm}$ menghadap ke depan

- Kemudian kaki yang lain tarik ke arah belakang lalu ayunkan ke arah bola

- Kunci engkel kaki untuk kekuatan perkenaan kaki pada bola

- Gunakan punggung kaki untung mengenai bola

- Posisi tubuh agak bcondong kedepan

- Keseimbangan menggunakan kedua tangan dengan tangan yang satu sisi dengan kaki tumpuan diangkat lebih tinggi dari tangan lain

Perkenaan Bola

- Perkenaan pada bola gunakan pada pertengahan bola sehingga bola tidak terlalu mendatar maupun melambung

- Lakuakn impact bola dengan secapar mungkin dengan perkenaan bola yang tepat

Gerakan Lanjutan 
- Lakukan gerakan lanjut dengan ayunan kaki mengikuti arahan bola

- Kemudian posisi tubuh secara keseruhan fleksibel dengan mengikuti arah bola

- Perhatikan betul tahapan-tahapan secara urut dan bersambungan menjadi gerakan yang kompleks menghasilkan teknik shooting yang benar.

Kesalahan yang sering terjadi Saat Melakukan Teknik Shooting Dalam Sepakbola :

- Jarak antar bola dengan sikap ancang-ancang terlalu jauh

- Jarak antar bola dengan sikap ancang-ancang terlalu dekat

- Engkel kaki tidak dikunci menyebabkan laju bola yang tidak bertenaga

- Ayunan kaki dari belakang tidak maksimal di dorong ke arah depan menyebabkan bola tidak maksimal

- Jarak tumpuan kaki pada bola terlalu jauh

- Jarak tumpuan kaki pada bola terlalu dekat

Cara Melakukan Latihan Teknik Shooting Dalam Sepakbola

- Shooting sasaran gawang kosong

- Shooting sasaran gawang menggunakan penjaga gawang

- Shooting sasaran 6 kotak sasaran

- Shooting sasaran 6 kotak sasaran menggunakan penjaga gawang

Lakukan 4 menu latihan dengan melakukan latihan dari minggu pertama menggunakan shooting sasaran gawang kosong sebanayak 4 kali latihan. Kemudian minggu kedua menggunakan Shooting sasaran gawang menggunakan penjaga gawang sebanyak 3 kali latihan. Selanjutnya minggu ketiga menggunakan shooting sasaran 6 kotak sasaran sebanyak 4 kali latihan. Lalu minggu keempat menggunakan shooting sasaran 6 kotak sasaran menggunakan penjaga gawang. 


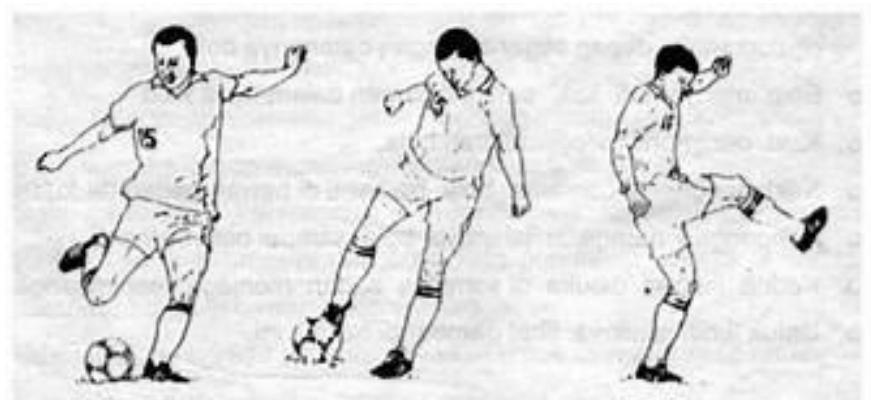

Gambar 4. Menendang dengan punggung kaki bagian dalam

4. Soal

1) Jelaskan apa yang dimaksud dengan shooting dalam sepak bola!

2) Apakah tujuan dari shooting?

3) Bagaimanakah perkenaan bola saat melakukan shooting?

4) Jelaskan posisi tubuh saat shooting!

5) Sebutkan 3 kesalahan dalam shooting!

6) Sebutkan 3 metode latihan shooting!

7) Sebutkan langkah-langkah melakukan shooting !

8) Jelaskan rangkaian metode latihan shooting!

9) Apakah perbedaan shooting di sepak bola dengan shooting di bola basket?

10) Apakah akibat jika pada saat shootingengkel kaki tidak dikunci Jawab

1) Shooting adalah gerakan mengarahkan bola ke arah gawang yang dijaga oleh seorang penjaga gawang.

2) Untuk memasukan bola ke arah gawang lawan dengan tendangan bola yang akurat menghindari halauan penjaga gawang.

3) Perkenaan pada bola adalah pada pertengahan bola sehingga bola tidak terlalu mendatar maupun melambung.

4) Posisi tubuh

a. Lakukan kaki tumpuan dengan menempatkan telapak kaki disamping bola dengan jarak $30 \mathrm{~cm}$ menghadap ke depan

b. Kemudian kaki yang lain tarik ke arah belakang lalu ayunkan ke arah bola

c. Kunci engkel kaki untuk kekuatan perkenaan kaki pada bola

d. Gunakan punggung kaki untung mengenai bola 
e. Posisi tubuh agak bcondongkedepan

f. Keseimbangan menggunakan kedua tangan dengan tangan yang satu sisi dengan kaki tumpuan diangkat lebih tinggi dari tangan lain.

5) Kesalahan pada saat melakukan shooting dalam permainan sepakbola

a. Jarak antar bola dengan sikap ancang-ancang terlalu jauhJarak antar bola dengan sikap ancang-ancang terlalu dekat

b. Engkel kaki tidak dikunci menyebabkan laju bola yang tidak bertenaga

6) Metode latihan shooting

a. Shooting sasaran gawang kosong

b. Shooting sasaran gawang menggunakan penjaga gawang

c. Shooting sasaran 6 kotak sasaran

7) Langkah-langkah melakukan

Awalan

- Ambil jarak dengan bola sejauh 1,5 meter

- Tempatkan bola di depan secara serong membentuk sudut 45 derajat

- Lari ke arah bola dengan melihat bgaian bola yang kan di tendang

\section{Posisi Tubuh}

- Lakukan kaki tumpuan dengan menempatkan telapak kaki disamping bola dengan jarak $30 \mathrm{~cm}$ menghadap ke depan

- Kemudian kaki yang lain tarik ke arah belakang lalu ayunkan ke arah bola

- Kunci engkel kaki untuk kekuatan perkenaan kaki pada bola

- Gunakan punggung kaki untung mengenai bola

- Posisi tubuh agak bcondongkedepan

- Keseimbangan menggunakan kedua tangan dengan tangan yang satu sisi dengan kaki tumpuan diangkat lebih tinggi dari tangan lain

\section{Perkenaan Bola}

- Perkenaan pada bola gunakan pada pertengahan bola sehingga bola tidak terlalu mendatar maupun melambung 
- Lakukan impact bola dengan secapar mungkin dengan perkenaan bola yang tepat

\section{Gerakan Lanjutan}

- Lakukan gerakan lanjut dengan ayunan kaki mengikuti arahan bola

- Kemudian posisi tubuh secara keseruhan fleksibel dengan mengikuti arah bola

- Perhatikan betul tahapan-tahapan secara urut dan bersambungan menjadi gerakan yang kompleks menghasilkan teknik shooting yang benar

8) Lakukan 4 menu latihan dengan melakukan latihan dari minggu pertama menggunakan shooting sasaran gawang kosong sebanayak 4 kali latihan. Kemudian minggu kedua menggunakan Shooting sasaran gawang menggunakan penjaga gawang sebanyak 3 kali latihan. Selanjutnya minggu ketiga menggunakan shooting sasaran 6 kotak sasaran sebanyak 4 kali latihan. Lalu minggu keempat menggunakan s shooting sasaran 6 kotak sasaran menggunakan penjaga gawang.

9) Shooting dalam permainan sepakbola pada dasarnya hampir sama seperti dalam shooting pada permainan bola basket memiliki tujuan untuk mengarahkan bola ke arah sasaran goal, dalam permainan sepakbola gawang yang dijaga oleh seorang penjaga gawang sedangkan dalam bola basket sasaran ke ring.

10) Menyebabkan laju bola yang tidak bertenaga. 


\section{BAB III}

\section{PENUTUP}

A. Kesimpulan

Sepak bola adalah cabang olahraga yang menggunakan bola sepak terbuat dari bahan kulit dan dimainkan oleh dua tim yang beranggotakan sebelas orang serta beberapa pemain cadangan”. Untuk memenangkan permainan ini kedua tim harus memasukkan bola ke gawang lawan tanpa menggunakan tangan. Tim yang berhasil membobol bola ke gawang lawan paling banyak akan menjadi pemenangnya. Pada dasarnya shooting sangat di perlukan dalam permainana sepak bola karena inti dari sebuah permainan sepak bola yaitu gool yang di cetak melalui shooting, Teknik dasar sepak bola dapat meliputi teknik-teknik dalam menendang, menggiring, mengontrol, menyundul, merebut, melempar ke dalam,

B. Saran

Kami sebagai peyusun makalah ini, sangat mengharap atas segala saran saran dan kritikan bagi pembaca yang kami hormati guna untu membangun pada masa yang akan datang untuk enjadi yang lebih baik dalam membenarkan alur alur yang semestinya kurang memuaskan bagi tugas yang kami laksanakan. 


\section{DAFTAR PUSTAKA}

Anonim, 2010 pengertian sepakbola, Arikelpdf diakses dari : https://jurnaldoc.com/jurnal-olahraga-sepak-bola-pdf/ pada tanggal 17 oktober 2020

Anonim, 2017 teknik shooting sepakbola, Artikelpdf diakses dari : https://penjasology.web.id/teknik-shooting-dalam-sepakbola/ pada tanggal 17 oktober 2020

Anonim, 2011 sejarah sepakbola, Artikelpdft diakses dar : https://www.jurnalponsel.com/sepak-bola/ pad tanggal 17 oktober 2020

Festiawan, R., Nurcahyo, P. J., \& Pamungkas, H. J. (2019). Pengaruh latihan small sided games terhadap kemampuan long pass pada peserta ekstrakurikuler sepakbola. Media ilmu keolahragaan Indonesia, 9(1), 18-22.

Festiawan, R. (2020). Pendekatan Teknik dan Taktik: Pengaruhnya terhadap Keterampilan Bermain Futsal. Gelanggang Olahraga: Jurnal Pendidikan Jasmani Dan Olahraga, 3(2), 143-155.

Sinatriyo, D., Kusuma, I. J., Festiawan, R., Kusnandar, K., \& Heza, F. N. (2020). Keseimbangan dan Kelentukan Pergelangan Kaki: Bagaimanakah Korelasinya dengan Kemampuan Shooting Sepakbola?. Media Ilmu Keolahragaan Indonesia, 10(1), 6-12.

Wicaksono, P. N., Kusuma, I. J., Festiawan, R., Widanita, N., \& Anggraeni, D. (2020). Penerapan pendekatan saintifik terhadap pembelajaran pendidikan jasmani materi teknik dasar passing sepak bola. Jurnal pendidikan jasmani Indonesia, 16(1), 41-54. 